\title{
Lead Absorption Abilities of Bougainvillea (Bougainvillea spectabilis Willd.) and Money Plant (Epipremnum aureum G. S. Bunting) in Lead-Based Paint Coated Compartments
}

\author{
Elsa May D. Baron ${ }^{12}$, Azraa Shakeelah Tomawis ${ }^{1}$, Malone Mary Briones ${ }^{1}$, \\ Danielle Andrea Ibaos ${ }^{1}$ and Ma. Catherine Sabando ${ }^{1}$ \\ ${ }^{1}$ Biology, Natural Sciences and Math Division, Arts and Sciences Department, San Pedro College \\ ${ }^{2}$ (Corresponding author: delimaelsa@yahoo.com)
}

Received: July 27, 2017; Accepted: February 22, 2018

\begin{abstract}
Lead has multiple detrimental effects in developing children and pregnant women. It can cause behavioral problems and decrease in IQ among children while complications may occur among pregnant women. This research is focused on two plants, Epipremnum aureum (money plant) and Bougainvillea spectabilis (bougainvillea), and their ability to sequester lead from air released by lead-based paint. The age of the plants (young or mature) and the type of plants were the factors used in the study. Each plant was placed inside a wooden compartment for seven days, where the interior surface was coated with lead-based paint. For baseline reading, one gram of leaves was collected from each plant before each was placed inside the painted compartment. Leaf samples were collected after the plants were placed inside the painted wooden compartments. The leaf samples were then subjected under atomic absorption spectroscopy to determine the amount of lead present. Results revealed that both Epipremnum aureum (money plant) and Bougainvillea spectabilis (bougainvillea) are capable of absorbing lead released in air from the lead-based paint coated compartments with differences at $2.4 \mathrm{ppm}$ and $14 \mathrm{ppm}$; respectively. Statistical analysis showed that there were no significant differences on the lead absorption abilities of Bougainvillea spectabilis and Epipremnum aureum based on age $(P=0.44)$. However, there was a significant difference in their capacity to absorb lead released in air based on the type of plant $(P=0.009)$.
\end{abstract}

Keywords: air pollution, heavy metal contamination, lead, paint, plants

Lead released in air is a public concern because it can inflict great damage to humans. When inhaled or ingested, it targets primarily the nervous system and its development. Lead poisoning can cause a number of ill effects to human health but it is more harmful to children especially in their neurological development. Lead is mainly sourced from vehicular emissions and in paints used to coat buildings (Juson, Martinez, and Ching, 2015).

Infrastructures are often painted for aesthetics as well as functionality to make areas brighter. There are many types of paints that are available in the market but the most marketable types of pigments are enamel paints. Lead compounds are added to increase the opacity and durability of oil-based enamel paints as well as speed up the drying process. As lead-based pigments are inorganic, lead makes the paint resistant against ultraviolet (UV) rays and heat that are both important characteristics for paint applications (Weinberg and Clark, 2012). Although international standards dictate that the lead content of paints should not exceed 90 ppm (Kessler, 2014), still a good number of paints that are available in the market have lead concentrations higher than the acceptable standard. As this is not strictly monitored by local and national authorities, this then poses a great risk of indoor lead poisoning (Calonzo et al., 2013; Boraches et al., 2014).

Plants have been explored in their capacity to remove heavy metals like lead from air. Bougainvillea (Bougainvillea spectabilis) and money plant (Epipremnum aureum) are some of the species explored for heavy metal phytoremediation in polluted air (Kulshreshtha, Rai, Mohanty, Roy, and 
Sharma, 2008; Sharma, Srivastava, and Roy, 2005; Deepalakshmi, Ramakrishnaiah, H., Ramachandra, and Kumar, 2014). As reported by Dela Cruz and colleagues in 2013 and Juson et al. (2015), B. spectabilis can absorb large amount of lead from air. Other than lead, bougainvillea is also capable of absorbing copper, zinc, and cadmium (Kumar, Arumgam, Anandakumar, Balakrishnan, and Rajavel, 2012). Aside from bougainvillea, E. aureum can also be utilized to purify the air. Oyabu and colleagues in 2003 reported the plant's ability to absorb lead released in air from engine exhaust. Both plants are common ornaments that are often utilized as both indoor and outdoor decorative plants.

Given the potential of money plant and bougainvillea to remove heavy metals from air including lead, this study was aimed at determining these plants' potential to absorb lead released in the surrounding air from lead-based paints used in the interior walls of compartments.

\section{Materials and Methods}

\section{Plant acquisition and exposure to paint}

Six pots of each B. spectabilis and E. aureum comprising of three young and three mature plants for each species were bought from Lorymar Gardens, Maligaya Village, Brgy. Catalunan Pequeno, Davao City and were transported to Catalunan Grande for acclimatization and exposure to lead-based paint. The age of the plants was identified mainly through leaf coloration such that young leaves of both bougainvillea and money plants have lighter shade of green compared to mature leaves (Lim, 2014; Govaerts, 2015). Only plants without diseased leaves were utilized in the study.

Twelve compartments measuring $84 \mathrm{~cm} \mathrm{x}$ $56 \mathrm{~cm}$ were constructed from a plywood sheet. The interior of the compartments were coated with 500 $\mathrm{ml}$ orange oil-based enamel paint. A potted plant was placed inside each box and was kept there for a week. Each compartment had four medium-sized holes drilled on the roof. Each hole measured 10 $\mathrm{cm}$ in diameter. This is to ensure that sunlight can still enter. The holes also served as vents for watering of plants.

The specific setup of the experiment was as follows: three (3) compartments for young $B$. spectabilis and three (3) compartments for old $B$. spectabilis; three (3) compartments for young $E$. aureum and three (3) compartments for old E. aureum. All compartments were stationed in an area covered with interspaced stands of trees. The lead content of the surrounding air inside the compartments, however, was not measured prior to placing the plants inside.

\section{Quantification of lead in the leaves of the test plants}

The baseline lead content was determined using atomic absorption spectroscopy. A gram of leaf samples was taken from each pot of plant (total of 12 samples) prior to placing them inside the painted compartments. Another reading was taken after one week of exposure to determine the lead absorptive ability of each plant. Readings were taken three times for each sample and average readings were obtained.

Lead was quantified from the leaves of each plant using flameless atomic absorption spectroscopy following procedures of Dela Cruz et al (2013) described earlier with slight modifications. Leaf samples of one gram per pot were obtained early in the morning, kept in a receptacle, and placed in a cold ice box for safety before they were transported to the laboratory. Immediately upon arrival in the laboratory, the leaves were oven-dried at $80^{\circ} \mathrm{C}$ for 24 hours. After drying, $10 \mathrm{ml}$ of mixed solution of nitric and hydrochloric acid $(8 \mathrm{~mL}$ HNO3: $2 \mathrm{~mL} \mathrm{HCl}$ ) were added to the samples which were left to submerge in the acidic solution for 2 hours at $200^{\circ} \mathrm{C}$ until the leaf fibers were digested and only wet salts remained. Samples were then diluted to $50 \mathrm{ml}$ with distilled water and filtered using Whatman ${ }^{\circledR} 41$ filter paper. The processed samples were analyzed by a graphite tube atomizer. Obtained readings of lead content of the leaves of the plant samples were statistically tested using Mann-Whitney U test.

\section{Results and Discussion}

\section{Volume of lead absorbed by the test plants}

Previous studies (Oyabu, Takenaka, Wolverton, Onodera, and Nanto, 2003; Rascioa and Navari-Izzo, 2011) noted the ability of the leaves of both $B$. spectabilis and E. aureum to absorb lead from the surrounding air. The lead content of each plant before and after exposure to the painted compartments was determined through atomic absorption spectroscopy. After a week of exposure, the lead content of young B. spectabilis leaves increased from $-3.984 \mathrm{ppm}$ to $18.55 \mathrm{ppm}$. Similarly, the lead content of the mature leaves of B. specta- 
bilis also increased from $8.89 \mathrm{ppm}$ to $24.50 \mathrm{ppm}$ after a week's exposure. The young leaves of $E$. aureum also showed augmented concentration of lead in its leaves from $11.56 \mathrm{ppm}$ to $13.96 \mathrm{ppm}$. In contrast, the mature leaves of E. aureum exhibited reduced concentration of lead from $14.2 \mathrm{ppm}$ to $10.02 \mathrm{ppm}$ after one week of exposure.

The mature bougainvillea leaves absorbed larger volume of lead compared to the younger leaves. Although, young plants may exhibit better heavy metal absorption abilities due to their higher physiological activities, mature plants that are bigger in size are able to take up more substantial volume of heavy metals (Tangahu et al., 2011). Also, mature leaves can accommodate higher volume of lead than young leaves since they are already an established organ and can therefore accommodate the physiological needs of the plant (Sharma and Dubey, 2005).

On the other hand, the young leaves of $E$. aureum have higher metabolic rates. The higher volume of lead absorbed on young money plants could be attributed to more open stomata on the leaves than those of matured leaves as they come with fully developed edges (Goto, 2012).

Unfortunately, the absorptive ability of the mature E. aureum plant leaves were not fully assessed because the leaves were drenched with rainwater as the compartments that contained the mature money plants were not fully shaded. Available lead in the air can be influenced by rainwater as lead may react with water and oxygen to form lead hydroxide (Tangahu et al., 2011). Moreover, it is possible that lead in the leaves may have leached out to react with rainwater and oxygen (Lopez, Meas, Gama, Borges, and Olguin, 2008). The amount of lead that leached was not measured in the study. Future studies should account for this to further validate the available lead in air that is not absorbed.

There appears to be no significant difference between the lead absorption abilities of $B$. spectabilis and E. aureum based on the age of the plants (Table 1). However, both plant species showed a significant difference in their abilities to absorb lead. Young plants are able to absorb higher amounts of lead than mature plants (Tangahu et al., 2011). B. spectabilis absorbed larger amount of lead compared to E. aureum because it is a hyperaccumulator(Shabala, 2012). Another factor that affected the lead uptake is the classification of plant - dicot or monocot. The study conducted by Sharma and Dubey in 2005 reported that dicots have more stomata compared to monocots thus enabling the dicot $B$. spectabilis to absorb more heavy metals like lead compared with the monocot $E$. aureum. The presence of lead as a stressor to plants can actually increase number of stomata in leaves as observed in soybean (Glycine max (L.) Merr.), another dicot plant (Chmielewska and Chwil, 2005). However, actual counts of the stomates in both plants used in this study were not determined.

The caveat of painting the compartment with fresh paint was that lead exposure might be too minimal. This is because lead in paint can only be released to the surrounding once the paint has peeled off. To ensure that lead was indeed circulating inside the compartment despite short exposure time, a single coating of the paint was applied to facilitate faster possible peeling off of the paint. Furthermore, plants need to have close contact with the lead-laden interior wall to increase the chance of absorbing lead released from the paint, thus this study opted to build small wooden compartments to house each plant.

Experimental set-up in the future should increase the exposure period to further establish the capacity of the plants to absorb lead from wall paints. Moreover, the volume of lead within the compartment prior to putting in the plants should also be quantified. This is to further asses if the lead absorbed by the plants is coming from the paint and not from the available lead in the air before the paint was applied.

\section{Acknowledgements}

The researchers are thankful to the logistical support provided by Dr. Ana Julia Enero, Dean of Arts and Sciences Department of San Pedro Col-

Table 1. Test for the significant difference of the lead absorption capacities of bougainvillea and money plant.

\begin{tabular}{cccc}
\hline Variable & P value & Decision & Interpretation \\
\hline Type of Plant & 0.009 & Reject Ho & Significant \\
Age & 0.44 & Accept Ho & Not Significant \\
\hline
\end{tabular}


lege and to Ms. Helen Ancla, Director of laboratories. We also sincerely thank Mrs. Loida Avorque, head of the Chemistry Laboratory of the Bureau of Fisheries and Aquatic Resources Region XI, who generously assisted the group in conducting the Atomic Absorption Spectroscopy (AAS) analysis of the samples.

\section{References}

Broaches, S., Denney, V., Weinberg, J., Manny, C.C., Withanage, H., and Clark, S. (2014). Asia Regional Paint Report. International POPs Elimination Network. Retrieved from: http://ipen.org/sites/default/files/documents/Asia\% 20Regional $\% 20$ Paint $\% 20$ Report\%20final.pdf.

Calonzo, M., Guarino, J., Tolibas, M.J.R., Lucero, A., Brosché, Dr. S, Clark, Dr. S., Valerie, D., and Weinberg, J. (2013). Philippine Paint Report 2013: Lead in New Enamel in Household Paints in the Philippines. International POPs Elimination Network. Retrievedfrom:http://ipen.org/sites/default/ files/documents/Philippine \%20Paint $\% 20$ Report $\%$ 202013\%20(FINAL).pdf.

Chmielewska, E., and Chwil, M. (2005). Leadinduced histological and ultrastructural changes in the leaves of soybean (Glycine $\max$ (L.) Merr.). Soil Science and Plant Nutrition, 51 (2), 203-212.

Deepalakshmi, A.P., Ramakrishnaiah, H., Ramachandra, Y.L., and Kumar, N. (2014). Leaves of Higher Plants as Indicators of Heavy Metal Pollution along the Urban Roadways. International Journal of Science and Technology, 3 (6), 340-346.

Dela Cruz, K.A.M., Burgos, S.D., Gloria, M.A., Ventura, K. M., and Solidum, J. (2013). Comparison of Lead Absorption Ability of Bougainvillea (Bougainvillea spectabilis L.) Leaves in Two Cities in Metro Manila, Philippines. International Journal of Bioscience, Biochemistry and Bioinformatics, 3(3), 192-195.

Goto, M. (2012). Fundamentals of Bacterial Plant Pathology. 2012 edition Academic Press. Technology \& Engineering. Agriculture. General.

Govaerts, R. (2015). World Checklist of Araceae Royal Botanic Gardens. Retrieved from: http://apps.kew.org/wcsp/

prepareCheck-
list.do;jsessionid=B204C17F56E91C22FE34AA3

FE74D418?checklist=selected_families $\% 40 \%$ 40042110220161843796.

Juson, A.E.D.S., Martinez, M.K.M. and Ching, J.A. (2015). Accumulation and Distribution of Heavy Metals in Leucaena leucocephala Lam. and Bougainvillea spectabilis Wild Plant Systems. Journal of Experimental Biology and Agricultural Sciences, 4(1), 1-6. doi: http:// dx.doi.org/10.18006/2015.4(1).01.06.

Kessler, R. (2014). Lead-based Decorative Paints: Where Are They Still Sold-and Why? Environmental Health Perspectives, 122(4), 96-103. doi: 10.1289/ehp.122-A96.

Kulshreshtha, K., Rai, A., Mohanty, C.S., Roy, R.K. and Sharma, S.C. (2008). Particulate Pollution Mitigating Ability of Some Plant Species. International Journal of Environmental Science, 3,137-142.

Kumar, S.R., Arumgam, T., Anandakumar, C.R., Balakrishnan, S. and Rajavel, D.S. (2012). Use of Plant Species in Controlling Environmental Pollution-A Review. Bulletin of Environment, Pharamacology, and Life Sciences, 2(2), 52-63.

Lim, T.K. (2014). Edible Medicinal and NonMedicinal Plants. Springer Science \& Business, 8, 489-494.

Lopez, R., Meas, Y., Gama, S., Borges, R., and Olguin, E. (2008). Leaching of lead by ammonium salts and EDTA from Salvinia minima biomass produced during aquatic phytoremediation. Journal of Hazardous Materials, 154, 623-632.

Oyabu, T., Takenaka, K., Wolverton, B., Onodera, T., and Nanto, H. (2003). Purification characteristics of golden pothos for atmospheric gasoline. International Journal of Phytoremediation, 5 (3), 267-276.

Rascioa, N., and Navari-Izzo, F. (2011). Heavy metal hyperaccumulating plants: How and why do they do it? And what makes them so interesting? Plant Science, 180, 169-181.

Shabala, S. (2012). Plant Stress Physiology. C.A.B. International.

Sharma, S.C., Srivastava R., and Roy, R.K. (2005). 
JEEAR, Vol. 1, 2018

Role of bougainvilleas in mitigation of environmental pollution. Journal of Environmental Science Engineering, 47(2), 131-134.

Sharma, P., and Dubey, R.S. (2005). Lead toxicity in plants. Brazilian Journal of Plant Physiology, 17 (1), 35-52.

Tangahu, B.V., Abdullah, S.R.S., Basri, H., Idris, M., Anuar, N., and Mukhlisin, M. (2011). A Review on Heavy Metals (As, $\mathrm{Pb}$, and $\mathrm{Hg}$ ) Uptake by Plants through Phytoremediation. International Journal of Chemical Engineering, 1-30. doi:10.1155/2011/939161.

Weinberg, J. and Clark, S. (2012). Global Lead Paint Elimination By 2020: A Test of Effectiveness of the Strategic Approach to International Chemical Management". International POP's Elimination Network. Retrieved from: http://ipen.org/sites/default/files/ documents/IPEN-Global-Lead-PaintEliminationReport2012-en.pdf. 